\title{
Cyclin-Dependent Kinase 5
}

National Cancer Institute

\section{Source}

National Cancer Institute. Cyclin-Dependent Kinase 5. NCI Thesaurus. Code C17785.

Cyclin-dependent kinase 5 (292 aa, $\sim 33 \mathrm{kDa}$ ) is encoded by the human CDK5 gene. This protein plays a role in protein phosphorylation and may be involved in cell cycle regulation. 